\title{
Külföldi munkavállalás és pályaelhagyási indítékok a magyar gyógytornászok körében
}

\author{
Pónusz Róbert ${ }^{1,4}$. Kovács Dalma ${ }^{1}$ \\ Raposa László Bence ${ }^{2}$ - Hock Márta dr. ${ }^{3}$ - Decsi Tamás dr. ${ }^{4}$ \\ Kránicz János dr. ${ }^{3}$. Endrei Dóra dr. ${ }^{1,4}$ \\ Pécsi Tudományegyetem, Egészségtudományi Kar, ${ }^{1}$ Egészségbiztosítási Intézet, \\ ${ }^{2}$ Táplálkozástudományi és Dietetikai Intézet, ${ }^{3}$ Fizioterápiás és Sporttudományi Intézet, Pécs \\ ${ }^{4}$ Pécsi Tudományegyetem, Klinikai Központ, Pécs
}

\begin{abstract}
Bevezetés: A magyar egészségügyi szférában munkát vállaló szakdolgozók körében növekvő tendenciát mutat a külföldi munkavállalás. Célkitúzés: A szerzők célja a magyar gyógytornászok migrációs és pályaelhagyási magatartáának, illetve a hátterében lévő főbb kiváltó tényező́k bemutatása. Módszer: 2014. áprilistól augusztusig országos felmérést végeztek a Magyarországon munkát vállaló gyógytornászok körében. Összesen 215 fó vett részt a felmérésben. Eredmények: Az eredmények szerint az életkor $(\mathrm{p}<0,05)$, illetve a munkahelyen tapasztalható anyagi megbecsülés mértéke $(\mathrm{p}<0,01)$ számottevő hatást gyakorol a migrációs gondolatok megjelenésére. Azon gyógytornászok, akik nem érzik anyagilag megbecsültnek magukat, több mint 55-szörös eséllyel vállalhatnak munkát az országhatáron kívül $(\mathrm{OR}=$ $55,28$, CI $[95 \%]=18,85-162,12)$. Ennek hátterében lévő leggyakoribb okok az anyagi és erkölcsi megbecsüléssel kapcsolatos elégedetlenség $(\mathrm{p}<0,01)$ mindkét esetben). Következtetések: Annak érdekében, hogy megelőzzük a szakképzett gyógytornászok külföldi munkavállalását, illetve pályaelhagyását, szükséges növelni az anyagi és erkölcsi megbecsülés mértékét a magyar egészségügyi ellátórendszerben. Orv. Hetil., 2016, 157(9), 342-349.
\end{abstract}

Kulcsszavak: egészségpolitika, humán erőforrás, migráció, pályaelhagyás, gyógytornász

\section{Motivations of foreign employment and carrier change among Hungarian physiotherapists}

Introduction: An increasing motivation can be experienced among professional workers within the Hungarian healthcare system towards foreign employment or career change. Aim: The aim of the authors was to assess Hungarian physiotherapists' migration and career changing behaviour and to understand the underlying factors. Method: A national survey in Hungary from April to August, 2014 was performed. Only physiotherapists who practice in Hungary were included $(\mathrm{n}=215)$. Results: The results suggest that age $(\mathrm{p}<0.05)$ and the rate of financial appreciation experienced in the workplace $(\mathrm{p}<0.01)$ significantly affect the appearance of migratory thoughts. Those physiotherapists who do not feel themselves financially appreciated, are 55 times more likely to search for employment outside the country's borders $[\mathrm{OR}=55.28 \mathrm{CI}(95 \%)=18.85$ to 161.12$]$. The most common causes for that are unfavourable financial $(\mathrm{p}<0.01)$ and moral recognition $(\mathrm{p}<0.01)$. Conclusions: In order to prevent our already highly-qualified colleagues from leaving the country or from considering to leave the profession we should concentrate on increasing the financial and moral appreciation of the profession within the Hungarian healthcare system.

Keywords: health policy, human resources, migration, career change, physiotherapist

Pónusz, R., Kovács, D., Raposa, L. B., Hock, M., Decsi, T., Kránicz, J., Endrei, D. [Motivations of foreign employment and carrier change among Hungarian physiotherapists]. Orv. Hetil., 2016, 157(9), 342-349.

(Beérkezett: 2015. december 10.; elfogadva: 2016. január 7.) 
Az egészségügyi szakembervándorlás globális jellegéből adódóan számos kutatási és egészségpolitikai kérdést vet fel. A képzett egészségügyi szakemberek iránt nagy igény mutatkozik szerte a világban, így esetükben szinte kötelezőnek számító külföldi tapasztalatszerzés során megélik, lehet a választott hivatást a hazaitól eltérő színvonalon és körülmények között is gyakorolni. Külföldi munkavállalás mellett rendszerint az alacsonyabb jövedelmú országok állampolgárai döntenek [1]. A nemzetközi migrációs folyamatok felerősödésének következtében az egészségügyi szféra egyes területein emberieróforrás-hiány tapasztalható, amely tovább növeli a migrációs magatartás hátterében lévô okok megismerésére való törekvést. Magyarország is jelentős, bár eltérő mértékû́ szakemberhiánnyal és -eloszlással kénytelen szembenézni, amely nem csupán földrajzilag és területileg, hanem egyes szakterületek között is tapasztalható. A magyar egészségügyi ellátórendszerben tapasztaltak sokakat külföldi munkavállalásra ösztönöznek, tovább erősítve ezzel azt a gyakorlatot, miszerint a magasabb jövedelmú országok egészségügyi ellátórendszere mindig vonzó célpont lesz a külföldi munkavállalást tervezők körében [2-4].

$\mathrm{Az}$ egészségügyi szakdolgozói pálya presztízse Magyarországon sosem tartozott az élmezőnybe, amely alól a gyógytornászszakma sem képez kivételt. Az egészségügyi ellátórendszerben tapasztalható negatívumok az orvostársadalom körében is tetten érhetók. Ennek okán e szakmacsoport körében is csökkenhet a szakmai megelégedettség mértéke, amely elővetítheti a külföldi munkavállalási magatartás felerősödését [5-8].

Vizsgálatunk célja a magyar egészségügyi ellátórendszerben munkát vállaló gyógytornászok migrációs és pályaelhagyási magatartásának felmérése. Átfogó információt szeretnénk közölni arról, hogy a vizsgálatban részt vevők munkahelyeinek típusa, az ott tapasztalt környezet minősége, valamint a munkavégzéshez társuló sajátosságok (például: munkahelyi stressz szintje, anyagi és erkölcsi megbecsülés mértékének alakulása) miként befolyásolják a megkérdezetteknél a külföldi munkavállalási, illetve a gyógytornászpálya elhagyása iránt érzett motiváció mértékét.

\section{Anyag és módszer}

Vizsgálatunk keresztmetszeti típusú, prospektív elemeket tartalmazó felmérés volt. Kizárólag azok a kollégák vehettek részt a felmérésben, akik a magyar egészségügyi ellátórendszer valamely progresszív betegellátási szintjén végeztek munkát a vizsgálat lebonyolításának időpontjában, amely 2014 áprilisától augusztusig tartott. Az adatelemzésból kizárásra kerültek a munkával nem rendelkező, illetve a már külföldön munkát vállaló gyógytornászok.

Országos felmérést végeztünk a fent említett időszakban, ennek következtében konkrét helyszín nem került meghatározásra. Az adatgyújtést egy saját szerkesztésű, illetve az Erőfeszítés-Jutalom Egyensúlytalanság Kérdő- ív validált, magyar fordításának segítségével bonyolítottuk le. Utóbbi felhasználása mind eredeti, mind magyar nyelven jól dokumentált [9]. Saját szerkesztésű kérdőívünket egy munkacsoport segítségével állítottuk össze: az ürlap segítségével szociodemográfiai adatokról, a munkahelyen tapasztalható sajátosságokról, a külföldi munkavállalási, pályaelhagyási hajlandóságról, illetve külföldi letelepedéssel kapcsolatos kérdésekről kívántunk átfogó ismereteket gyújiteni. Az Erőfeszítés-Jutalom Egyensúlytalanság Kérdőív felhasználását a munkahelyi stressz-szint mérése, illetve a segítségével kapott méröszám, az általunk vizsgált munkavállalási magatartások párhuzamba állítása indikálta.

A kérdő́ivek a Magyar Gyógytornász-Fizioterapeuták Társasága Dél-dunántúli Régiójának havi hírleveléhez csatoltan, online formában, továbbá kényelmi szempontok figyelembevételével kerültek kiosztásra. A kiküldött 340 példányból 215 volt értékelhető (válaszadási arány: $62,23 \%)$. Ez a válaszadási arány az online vizsgálatok részvételi hajlandóságához viszonyítva megfelelőnek minősíthető [10]. Eredményeinket az SPSS 20.0 verziójú programmal elemeztük, leró statisztikai, $\chi^{2}$-, MannWhitney- és Kruskal-Wallis-tesztet, lineáris regressziót, illetve varianciaanalízist alkalmaztunk. Szignifikanciahatárunk $\mathrm{p}<0,05$ volt.

\section{Eredmények}

\section{Szociodemográfiai mutatók alakulása}

Vizsgálatunkban 215 fó vett részt $(\mathrm{n}=215)$, a nemek megoszlása pedig a következőképp alakult: $94,4 \%$ nő $(\mathrm{n}=203)$ és $5,6 \%$ férfi $(\mathrm{n}=12)$. A megkérdezettek átlagéletkora 32,75 év $(S D=9,125)$ volt. A felmérésben szereplőket életkoruk alapján három csoportba osztályoztuk: 20-30 évesek $(\mathrm{n}=171), 31-40$ évesek $(\mathrm{n}=31)$, valamint 40 év felettiek $(n=13)$. A különféle családi állapotok megjelenítésére az alábbi kategóriákat hoztuk létre: egyedülálló $(\mathrm{n}=34)$, házastárssal/élettárssal élő $(\mathrm{n}=78)$, házastárssal/élettárssal + gyermekkel élő $(\mathrm{n}=76)$, egyéb családtaggal élő $(\mathrm{n}=25)$, illetve egyéb személlyel élő $(n=2)$. Jelenlegi anyagi helyzetüket a következőképpen ítélték a minta tagjai: átlagos $(\mathrm{n}=182)$, az átlagosnál jobb $(\mathrm{n}=17)$, valamint az átlagosnál roszszabb $(\mathrm{n}=16)$. A megkérdezettek többsége föiskolai diplomával $(\mathrm{n}=186)$, míg 40,9\% a gyógytornászszakmáján kívül más végzettséggel is rendelkezik $(\mathrm{n}=88)$. $51,62 \%$ másodállást is vállal annak érdekében, hogy havi jövedelmét kiegészítse $(\mathrm{n}=111)$. Legalább egy nyelvvizsgája van a válaszadók $82,3 \%$-ának $(\mathrm{n}=177)$, közülük $14,4 \%$ kettő $(\mathrm{n}=31), 1,4 \%$ pedig kettőnél több sikeres nyelvvizsgát abszolvált eddig $(\mathrm{n}=3)$. A vizsgálatban részt vevő kollégákat szociodemográfiai, illetve a munkavégzéshez kapcsolódó sajátosságaik alapján csoportosítottuk, amelyről az 1. táblázatban található bővebb információ. 


\section{A saját szerkesztésü kérdőínünk eredményei}

A jelenlegi munkahelyen töltött évek száma szerinti kategorizálás alapján öt csoportot hoztunk léte: $0-5$ éve dolgozók ( $\mathrm{n}=138), 6-10$ éve $(\mathrm{n}=28), 11-15$ éve $(\mathrm{n}=22)$, 16-20 éve $(\mathrm{n}=12)$, valamint a 20 évnél régebb óta jelenlegi munkahelyükön dolgozók $(\mathrm{n}=14)$. A heti munkaórák száma alapján három csoport került megalkotásra: hetente kevesebb mint 40 órát $(\mathrm{n}=28)$, hetente 40 és 50 óra között $(\mathrm{n}=160)$, illetve a hetente több mint 50 órát dolgozók $(\mathrm{n}=27)$. Fontosnak tartottuk összehasonlítani a jelenlegi munkahelyen töltött évek számát a heti munkaórák számával. Eredményeink szerint a jelenlegi munkahelyen töltött évek száma szignifikánsan nem befolyásolja a minta ledolgozott heti munkaóráinak számát $(\mathrm{p}=0,667)$.

A válaszadók $45,6 \%$-a véli úgy, jelenlegi idegennyelvismerete nem akadályozná abban, hogy külföldön, gyógytornászként vállaljon munkát $(\mathrm{n}=98)$. Mintánk tagjainak 97,7\%-a tett már lépést szakmai színvonalának javítása érdekében $(\mathrm{n}=210)$. Ezen tevékenységek az alábbiak: fizioterápiás tanfolyamon $(\mathrm{n}=180)$, szakmaspecifikus konferenciákon történő részvétel $(\mathrm{n}=135)$, szakmai folyóiratok $(\mathrm{n}=150)$, valamint fizioterápiás protokollok tanulmányozása $(\mathrm{n}=94)$. A vizsgálatban részt vevők $54,4 \%$-a átlagon felülinek ítélte a gyógyítás iránt érzett motivációjának mértékét ( $\mathrm{n}=117)$, amelyre számottevő hatást fejt ki, hogy a kolléga tett-e már lépéseket szakmai színvonalának javítása érdekében $(\mathrm{p}<0,01)$. A válaszadók többsége legalább jónak ítélte meg a munkahelyén tapasztalható környezet $(\mathrm{n}=103)$, illetve a kollégákkal való kapcsolatának minőségét $(\mathrm{n}=112)$. Eredményeink szerint a munkahely típusa jelentősen befolyásolja mind a munkahelyi környezet $(p<0,01)$, mind a kollegiális kapcsolatok alakulását $(\mathrm{p}<0,01)$.

A válaszadók mindössze 6,5\%-a nyilatkozott úgy, hogy teljes mértékben elégedett a munkájáért járó anyagi javadalmazás mértékével $(\mathrm{n}=14)$. Ezen csoport $50 \%$-a a magánszférában munkát vállalók közül került ki $(\mathrm{n}=7)$. Eredményeink szerint, a munkahely típusa jelentős hatást gyakorol az ott tapasztalható anyagi megbecsülés mértékére is $(p<0,01)$. Nem tudunk beszámolni számottevő összefüggésről az életkor $(\mathrm{p}=0,387)$, a háztartás összetétele $(\mathrm{p}=0,122)$, valamint a legmagasabb iskolai végzettség $(\mathrm{p}=0,884)$ anyagi megbecsülés mértékét befolyásoló hatásáról. A gyógytornászpálya nehézségeinek tudatában a megkérdezettek $66,5 \%$-a ajánlaná ismerőseinek a szakmát ( $\mathrm{n}=143)$, míg 70,7\%-uk ugyancsak gyógytornásznak tanulna abban az esetben, ha újrakezdhetné tanulmányait $(\mathrm{n}=152)$.

\section{A külföldi munkavállalással kapcsolatos eredmények}

Mintánk 43,7\%-át foglalkoztatja a külföldi munkavállalás lehetôsége ( $\mathrm{n}=94)$, amelyet jelentős mértékben befolyásol a válaszadó neme $(\mathrm{p}<0,05)$, munkahelyének típusa
1. táblázat A minta tagjainak szociodemográfiai és a munkavégzéshez társuló jellemzóinek bemutatása $(\mathrm{n}=215)$

\begin{tabular}{|c|c|c|c|c|c|}
\hline Nem & $\mathrm{N}$ & $\%$ & $\begin{array}{l}\text { Gyógytornásztól } \\
\text { eltéró végzettség }\end{array}$ & $\mathrm{N}$ & $\%$ \\
\hline Férfi & 13 & $6,05 \%$ & Van & 88 & $40,93 \%$ \\
\hline Nó & 202 & $93,95 \%$ & Nincs & 127 & $59,07 \%$ \\
\hline \multicolumn{3}{|l|}{ Életkor } & \multicolumn{3}{|l|}{ Anyagi helyzet } \\
\hline 20-30 év & 171 & $79,53 \%$ & Átlagos & 182 & $84,65 \%$ \\
\hline 31-40 év & 31 & $14,42 \%$ & Átlag feletti & 17 & $7,91 \%$ \\
\hline 40 év felett & 13 & $6,05 \%$ & Átlag alatti & 16 & $7,44 \%$ \\
\hline \multicolumn{3}{|l|}{$\begin{array}{l}\text { Háztartás } \\
\text { összetétele }\end{array}$} & \multicolumn{3}{|l|}{$\begin{array}{l}\text { Munkahelyen } \\
\text { töltött évek száma }\end{array}$} \\
\hline Egyedülálló & 34 & $15,81 \%$ & $0-5$ év & 138 & $64,19 \%$ \\
\hline $\begin{array}{l}\text { Házastárs / } \\
\text { élettárs }\end{array}$ & 78 & $36,28 \%$ & 6-10 év & 28 & $13,02 \%$ \\
\hline $\begin{array}{l}\text { Házastárs / } \\
\text { élettárs + } \\
\text { gyermek }\end{array}$ & 76 & $35,35 \%$ & $11-15$ év & 22 & $10,23 \%$ \\
\hline Egyéb családtag & 25 & $11,63 \%$ & 15-20 év & 13 & $6,05 \%$ \\
\hline Egyéb személy & 2 & $0,93 \%$ & 20 évnél több & 14 & $6,51 \%$ \\
\hline \multicolumn{3}{|l|}{ Főállása } & \multicolumn{3}{|l|}{$\begin{array}{l}\text { Másodállással } \\
\text { rendelkezik }\end{array}$} \\
\hline Egyetemi klinika & 37 & $17,21 \%$ & Igen & 111 & $51,63 \%$ \\
\hline Megyei kórház & 35 & $16,28 \%$ & Nem & 104 & $48,37 \%$ \\
\hline Városi kórház & 54 & $25,12 \%$ & $\begin{array}{l}\text { Heti munkaórák } \\
\text { száma }\end{array}$ & & \\
\hline Magánrendelés & 18 & $8,37 \%$ & $\begin{array}{l}\text { Kevesebb mint } \\
40 \text { óra }\end{array}$ & 28 & $13,02 \%$ \\
\hline $\begin{array}{l}\text { Oktatási } \\
\text { intézmény }\end{array}$ & 17 & $7,91 \%$ & 40-50 óra között & 160 & $74,42 \%$ \\
\hline Szakrendelő & 15 & $6,98 \%$ & Több mint 50 óra & 27 & $12,56 \%$ \\
\hline Gyógyfürdő & 11 & $5,12 \%$ & \multicolumn{3}{|l|}{$\begin{array}{l}\text { Legmagasabb } \\
\text { iskolai végzettség }\end{array}$} \\
\hline $\begin{array}{l}\text { Rehabilitációs } \\
\text { intézet }\end{array}$ & 10 & $4,65 \%$ & Főiskolai diploma & 186 & $86,51 \%$ \\
\hline Szociális otthon & 8 & $3,72 \%$ & Egyetemi diploma & 28 & $13,02 \%$ \\
\hline $\begin{array}{l}\text { Otthonápolási } \\
\text { szolgálat }\end{array}$ & 6 & $2,79 \%$ & Doktori iskola & 1 & $0,47 \%$ \\
\hline Egyéni vállalkozó & 3 & $1,40 \%$ & \multicolumn{3}{|l|}{ Nyelvvizsga } \\
\hline Sportegyesület & 1 & $0,47 \%$ & Nincs & 38 & $17,67 \%$ \\
\hline \multicolumn{3}{|l|}{ Lakhelye } & 1 & 143 & $66,51 \%$ \\
\hline Fôváros & 21 & $9,77 \%$ & 2 & 31 & $14,42 \%$ \\
\hline Megyeszékhely & 51 & $23,72 \%$ & 2-nél több & 3 & $1,40 \%$ \\
\hline Város & 112 & $52,09 \%$ & \multirow{3}{*}{\multicolumn{3}{|c|}{$\begin{array}{l}\text { Tett már lépést } \\
\text { szakmai színvona- } \\
\text { lának javítása } \\
\text { érdekében }\end{array}$}} \\
\hline Falu & 31 & $14,42 \%$ & & & \\
\hline \multirow[t]{3}{*}{ Külterület } & 0 & $0,00 \%$ & & & \\
\hline & & & Igen & 210 & $97,67 \%$ \\
\hline & & & Nem & 5 & $2,33 \%$ \\
\hline
\end{tabular}

$(\mathrm{p}<0,05)$, idegennyelv-ismerete $(\mathrm{p}<0,01)$, valamint az életkora $(\mathrm{p}<0,05)$. A válaszadó férfiak körében a külföldi munkavállalási hajlandóság 75\% ( $\mathrm{n}=9$ ), míg a nők eseté- 
ben $41,87 \%(\mathrm{n}=85)$. A statisztikai próbák elvégzése után kijelenthetjük, hogy a nem számottevő hatást gyakorol a külföldi munkavállalási magatartás megjelenésére $(\mathrm{p}<0,01)$. Eredményeinkben a férfi nem, mint hajlamosító tényező jelenik meg a nemzetközi migrációval kapcsolatos szándékot vizsgálva $(\mathrm{OR}=4,1$, CI [95\%] = 1,095-15,843). A migrációs gondolatok megjelenése leginkább a 20-30 évesek korcsoportjánál volt kifejezett $(\mathrm{n}=81)$. Azok a gyógytornászok, akik fontolgatják a külföldi munkavállalást, többségében gyermekkel nem rendelkező párok tagjai $(\mathrm{n}=31)$. A háztartás összetétele nem befolyásolja szignifikáns módon a minta migrációs gondolatának megjelenését $(p=0,126)$. A jelenlegi anyagi helyzet minősége ugyanakkor számottevő hatást gyakorol a külföldi munkavállalással kapcsolatos hajlandóság alakulására $(\mathrm{p}<0,05)$. Az országhatáron túli munkavégzést mérlegelők 69,14\%-a legfeljebb 5 éve dolgozik jelenlegi munkahelyén $(\mathrm{n}=65)$. Eredményeink alapján, a jelenlegi munkahelyen töltött évek száma jelentős hatást gyakorol a külföldi munkavállalással kapcsolatos tervek meglétére $(\mathrm{p}<0,05)$. A migrációs gondolatokkal rendelkezők 95,74\%-a a kedvezőbb anyagi megbecsülést tartja a legfőbb kiváltó oknak, amely a külföldi munkavállalást előrevetítheti $(\mathrm{n}=90)$. A KruskalWallis-teszt elvégzése után megállapítottuk, hogy a munkahelyen tapasztalható kedvezőtlen anyagi megbecsülés szignifikáns módon befolyásolja a migrációs magatartás bekövetkezését $(\mathrm{p}<0,01)$, továbbá a célországban tapasztalható kedvezőbb anyagi javadalmazás iránti vágy jelentős hatást gyakorol a külföldi munkavállalási hajlandóságra is $(\mathrm{p}<0,01)$. Több mint 55 -szörös esélye van azon gyógytornászok külföldön történő munkavállalásának bekövetkezésére, akik valamilyen formában elégedetlenségüket fejezték ki a munkahelyen tapasztalható anyagi megbecsüléssel kapcsolatban $(\mathrm{OR}=55,286$, CI [95\%] = 18,853-162,126). Ezenkívül az erkölcsi megbecsülésben tapasztalható hiányosságok több mint ötszörös eséllyel vetíthetik előre a külföldi munkavállalással kapcsolatos magatartás bekövetkezését $(\mathrm{OR}=5,410, \mathrm{CI}$ [95\%] = 2,554-11,460). Szakmailag előrelépésként tekint az országhatáron túli munkavállalásra a válaszadók 20,46\%-a (n = 44), míg a minta tagjainak közel negyede a munkavégzés során használt korszerütlen eszközök miatt döntene a külföldön, gyógytornászszakmában történő elhelyezkedés mellett $(\mathrm{n}=53)$. Vizsgálatunk szerint a kalandvágy is motivációs tényező a nemzetközi migrációs magatartásban: a minta tagjai 14,88\%-ban vállalnának munkát az országhatáron kívül kalandvágyuk kielégítéséből fakadóan $(\mathrm{n}=32)$. Eredményeink szerint a szakmai kihívás $(\mathrm{p}<0,01)$, a korszerübb eszközökkel történő munkavégzés $(\mathrm{p}<0,01)$, illetve a kalandvágy megléte $(\mathrm{p}<0,01)$ számottevő hatást gyakorol az országhatáron túli munkavállalás bekövetkezésére.

\section{Az országhatáron túli letelepedéssel kapcsolatos eredmények}

A válaszadók 75,3\%-a szeretne gyermeket vállalni a jövőben $(\mathrm{n}=162)$. Annak ellenére, hogy a vizsgálat lebonyolításának idején a minta tagjainak $43,7 \%$-a fontolgatta a külföldi munkavállalást ( $\mathrm{n}=93)$, mégis számos motivációs tényezőt jeleztek a válaszadók, amelyek egy esetlegesen bekövetkező, külföldi családalapítás mellett szólnak. A külföldi letelepedés mellett szóló érvek vizsgálatánál a válaszadók több lehetőséget is megjelölhettek, ezek közül a legjelentősebbek a következők: a hazaitól kedvezőbb financiális megbecsülés $(\mathrm{n}=101)$, a célországban tapasztalható kiegyensúlyozott élet $(\mathrm{n}=$ 78), illetve a kiszámítható gazdasági rendszer iránti vágy $(\mathrm{p}<0,01)(\mathrm{n}=56)$. Eredményeink szerint a kedvezőbb anyagi feltételek $(\mathrm{p}<0,01)$, illetve a kiegyensúlyozott élet reménye $(\mathrm{p}<0,01)$ számottevő hatást gyakorol a külföldi családalapítással kapcsolatos gondolatok megjelenésére is. Hasonló kapcsolatot sikerült kimutatnunk a külföldön történő letelepedés és a célországban tapasztalt kedvezőbb adórendszer $(\mathrm{p}<0,05)$, a más környezet iránti vágy $(\mathrm{p}<0,01)$, valamint a kiszámíthatóbb gazdasági sajátosságok között is $(\mathrm{p}<0,01)$. Az országhatáron túli letelepedés mellett szóló érvek a 2. táblázatban kerültek bemutatásra.

\section{A pályaelhagyási magatartással kapcsolatos evedmények}

A pályaelhagyási magatartás vizsgálatánál paradox helyzettel voltunk kénytelenek szembesülni, ugyanis a megkérdezettek több mint fele gondolt már arra, hogy számára kedvezőbb döntésnek bizonyulna, ha elhagyná a gyógytornászpályát $(\mathrm{n}=109)$, annak ellenére, hogy a minta tagjainak 70,7\%-a válaszolt úgy, hogy nem bánta meg választását a szakmáját illetően $(\mathrm{n}=152)$. Közel a minta tagjainak negyede $(23,25 \%)$ fontolgatja úgy a külföldön történő munkavállalást, hogy annak bekövetkezése esetén nem a gyógytornászszakmában helyezkedne el $(\mathrm{n}=50)$. Azon kollégák, akik fel kívánják adni a gyógy-

2. táblázat |A külföldi letelepedés mellett szóló érvek a mintában $(\mathrm{n}=215)$

\begin{tabular}{ll}
\hline A külföldi letelepedés mellett szóló főbb érvek & N \\
\hline Kedvezóbb anyagi feltételek & 101 \\
Kiegyensúlyozott élet iránti vágy & 78 \\
Kiszámíthatóbb gazdasági rendszer & 56 \\
Jobb egészségügyi rendszer & 43 \\
Kedvezóbb adórendszer & 29 \\
Más környezet iránti vágy & 17 \\
Kalandvágy & 12 \\
\hline
\end{tabular}


tornászpályát, közel két és félszeres eséllyel tehetik ezt meg Magyarországon kívül $(\mathrm{OR}=2,495$, CI [95\%] = 1,237-5,035). A gyógytornászpálya elhagyásának hátterében a minta egésze a kedvezőtlen anyagi megbecsülést $(\mathrm{n}=65)$, majd a munkahelyen tapasztalható erkölcsi megbecsülésben tapasztalható diszkrepanciát $(\mathrm{n}=42)$ jegyezte fel. Gyakori válasz volt még a szakmai előrelépés hiánya $(\mathrm{n}=32)$, illetve a korszerütlen eszközökkel történő munkavégzés is $(\mathrm{n}=30)$. Eredményeink szerint számottevően befolyásolja a pályaelhagyási gondolatok megjelenését mind a kedvezőtlen anyagi megbecsülés $(\mathrm{p}<0,01)$, mind az erkölcsi megbecsülésben tapasztalható elégedetlenség $(\mathrm{p}<0,01)$. Ezenkívül a szakmai előrelépés hiánya $(\mathrm{p}<0,01)$, a korszerütlen eszközökkel történó munkavégzés $(\mathrm{p}<0,01)$, valamint a gyógytornásztól eltérô végzettség megléte is $(\mathrm{p}<0,05)$ jelentős hatást gyakorol a pályaelhagyási magatartás bekövetkezésére. A gyógytornásztól eltérő végzettség $(\mathrm{OR}=2,745, \mathrm{CI}$ $[95 \%]=1,447-5,210)$, a kedvezötlen anyagi $(\mathrm{OR}=$ $5,530$, CI $[95 \%]=2,368-12,911)$ és erkölcsi megbecsülés is $(\mathrm{OR}=5,045, \mathrm{CI}[95 \%]=2,332-10,918)$ hajlamosító tényezőként jelenik meg a pályaelhagyási magatartás vizsgálata során. Nem tudunk ugyanakkor szignifikáns összefüggésról beszámolni a munkahelyi környezet ( $\mathrm{p}=$ $0,421)$, a jelenlegi anyagi helyzet $(\mathrm{p}=0,068)$, valamint a szakmai színvonal szubjektíven megítélt mértéke és a válaszadók pályaelhagyási magatartásának bekövetkezése között $(\mathrm{p}=0,526)$. Mintánk tagjainak 66,97\%-a életének valamely aspektusával kapcsolatban, részben vagy teljes mértékben elégedetlen $(\mathrm{n}=144)$.

\section{Az Eröfeszités-Jutalom Egyensúlytalanság Kérdōiv eredményei}

Az Erőfeszítés-Jutalom Egyensúlytalanság Kérdőív erőfeszítés dimenziójában elérhető pontok 3-15-ig terjedtek. A minta által tett erőfeszítés összpontszámának átlaga 8,055 pont volt $(S D=2,931)$. A jutalom faktor esetén az alacsonyabb összeget tekintettük a kedvezőtlenebbnek, ugyanis ebben az esetben kevesebb jutalmat kap munkahelyén a válaszadó. Az elérhető pontszámok 6-30 között lettek meghatározva. A minta jutalomértékének átlaga 15,362 pont volt $(S D=5,550)$. A túlvállalásértékek 10-22 pont közötti szélső értékekkel rendelkeztek: a dimenzió átlagértéke a mintában 15,209 pont volt $(\mathrm{SD}=2,311)$. Az erőfeszítés- és a jutalomskálák hányadosa képezte a munkavégzés során átélt stresszmérő számot. A megkérdezettek stresszpontszámának átlagértéke 0,579 volt $(\mathrm{SD}=0,277)$. A stresszmérő szám átlagértéke a férfiak csoportjában $(\mathrm{ER}=0,754$, $\mathrm{SD}=0,310)$ jóval magasabbnak bizonyult, mint a nőknél $(\mathrm{ER}=0,577, \mathrm{SD}=0,273)$, azonban a válaszadó neme jelentősen nem befolyásolta a munkahelyi stressz szintjének értékét $(\mathrm{p}=0,087)$. Eredményeink szerint a gyermekkel rendelkező párok stresszpontszáma bizonyult a legkedvezőbbnek, a munkahelyi stressz-szint és a családi állapot összehasonlítása során $(\mathrm{ER}=0,557$,

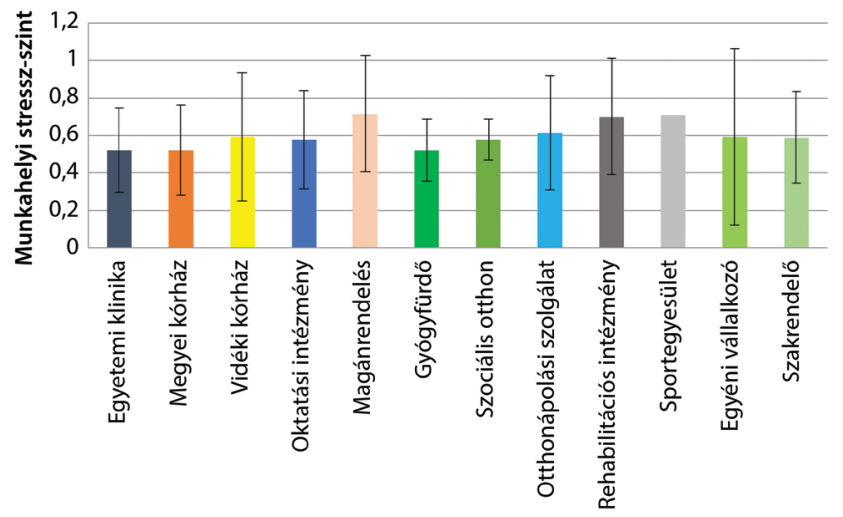

1. ábra A munkahelyi stressz-szint átlagértékeinek alakulása a munkahe lyek tekintetében

$\mathrm{SD}=0,261)$. A varianciaanalízis elvégzése után kijelenthetjük, hogy a háztartás összetétele, a munkahely típusa, valamint a munkahelyi környezet minősége nem befolyásolja számottevően a munkahelyi stressz-szint mértékét $(\mathrm{p}=0,574 ; \mathrm{p}=0,503 ; \mathrm{p}=0,468)$. A válaszadók munkahelyi stressz-szintjének átlagértékeit az 1. ábra és a 3. táblázat illusztrálja.

Mintánk tagjainak körében az átlag feletti anyagi helyzettel rendelkezők $(\mathrm{ER}=0,662, \mathrm{SD}=0,300)$ magasabb stresszhányadost értek el a skálán, mint a szerényebb jövedelmú kollégáik ( $\mathrm{ER}=0,569, \mathrm{SD}=0,274)$, azonban az anyagi helyzet minősége számottevő hatást nem gyakorol a munkahelyi stressz-szint mértékére $(\mathrm{p}=0,398)$. Hasonló eredményről tudunk beszámolni az életkor függő változót befolyásoló hatásáról is $(\mathrm{p}=0,146)$. A két változó között ugyanakkor egy pozitív irányú, gyenge lineáris kapcsolat volt kimutatható $\left(r=0,348, r^{2}=0,430\right.$, CI $[95 \%]=0,005-0,024)$. A válaszadók 71,6\%-a stabilnak véli jelenlegi munkahelyi pozícióját $(\mathrm{n}=154)$, míg a minta 76,4\%-a számolt be arról, hogy a közeljövőben nem lát esélyt arra, hogy elóléptessék $(n=165)$. Eredményeink szerint az állás bizonytalanságának megítélése $(\mathrm{p}<0,01)$ és az előléptetésre való korlátozott esély $(\mathrm{p}<0,01)$ jelentősen befolyásolja a minta stressz-szintjének mértékét. Nem tudtunk ugyanakkor szignifikáns összefüggésről beszámolni a munkahelyi stressz-szint külföldi munkavállalást ( $\mathrm{p}=0,486)$, illetve pályaelhagyást befolyásoló hatásáról $(\mathrm{p}=0,959)$.

\section{Megbeszélés}

Az utóbbi időben felerősödő, az egészségügyi szakdolgozók körében tapasztalható nemzetközi migrációs magatartás alól a gyógytornász-szakmacsoport képviselői sem képeznek kivételt. Hazai viszonylatban még ez irányú felmérés nem készült, ezért úgy véltük, a jelenség megértésében vizsgálatunk segítséget nyújthat azok számára, akik e szakmacsoport migrációs és pályaelhagyási habitusáról szeretnének bővebben informálódni. Számos vizsgálatban lejegyzésre került, hogy az egészségügyi szférában való munkavégzés fizikai, illetve lelki megter- 
3. táblázat |Az Erőfeszítés-Jutalom Egyensúlytalanság Kérdőív dimenzióinak értékei a mintában $(\mathrm{n}=215)$

\begin{tabular}{|c|c|c|c|c|c|c|c|c|}
\hline & \multicolumn{2}{|c|}{ Erőfeszítés } & \multicolumn{2}{|l|}{ Jutalom } & \multicolumn{2}{|c|}{ Egyensúlytalanság } & \multicolumn{2}{|c|}{ Erőfeszítés/jutalom } \\
\hline & Átlag & Szórás & Átlag & Szórás & Átlag & Szórás & Átlag & Szórás \\
\hline$N=215$ & 8,055 & 2,931 & 15,362 & 5,551 & 15,209 & 2,311 & 0,579 & 0,277 \\
\hline Férfi & 8,757 & 1,815 & 14,083 & 5,177 & 14,751 & 2,005 & 0,712 & 0,311 \\
\hline Nő & 8,014 & 2,982 & 15,438 & 5,574 & 15,236 & 2,331 & 0,571 & 0,273 \\
\hline 20-30 éves & 8,029 & 2,919 & 15,719 & 5,756 & 15,234 & 2,278 & 0,566 & 0,274 \\
\hline $31-40$ éves & 7,935 & 3,182 & 14,293 & 4,605 & 15,129 & 2,445 & 0,595 & 0,266 \\
\hline 40 évnél idősebb & 8,055 & 2,594 & 13,231 & 4,166 & 15,077 & 2,596 & 0,721 & 0,316 \\
\hline Hetente kevesebb mint 40 órát dolgozik & 7,731 & 3,084 & 15,250 & 5,355 & 14,941 & 2,196 & 0,556 & 0,282 \\
\hline Hetente 40-50 óra között dolgozik & 8,321 & 2,911 & 15,131 & 5,915 & 15,463 & 2,456 & 0,621 & 0,314 \\
\hline Hetente több mint 50 órát dolgozik & 8,387 & 2,417 & 16,355 & 5,232 & 15,387 & 2,194 & 0,543 & 0,163 \\
\hline Jelenlegi munkahelyén 0-5 éve dolgozik & 8,015 & 2,892 & 16,094 & 5,717 & 15,298 & 2,354 & 0,547 & 0,255 \\
\hline Jelenlegi munkahelyén 6-10 éve dolgozik & 8,286 & 3,053 & 14,107 & 5,258 & 14,643 & 2,076 & 0,657 & 0,348 \\
\hline Jelenlegi munkahelyén 11-15 éve dolgozik & 7,773 & 2,894 & 14,545 & 5,544 & 15,091 & 2,022 & 0,603 & 0,293 \\
\hline Jelenlegi munkahelyén 16-20 éve dolgozik & 8,021 & 3,104 & 13,751 & 3,467 & 15,583 & 2,712 & 0,602 & 0,236 \\
\hline Jelenlegi munkahelyén több mint 20 éve dolgozik & 8,143 & 3,183 & 12,786 & 4,611 & 15,286 & 2,614 & 0,691 & 0,322 \\
\hline Átlag alatti anyagi helyzet & 9,687 & 2,982 & 17,625 & 5,439 & 16,875 & 2,305 & 0,611 & 0,287 \\
\hline Átlagos anyagi helyzet & 7,945 & 2,862 & 15,379 & 5,468 & 15,044 & 2,241 & 0,569 & 0,274 \\
\hline Átlag feletti anyagi helyzet & 7,706 & 3,312 & 13,058 & 5,942 & 15,412 & 2,551 & 0,663 & 0,347 \\
\hline Gyógyítás iránti motiváció átlag alatti & 10,143 & 1,864 & 22,296 & 5,936 & 15,287 & 3,683 & 0,475 & 0,098 \\
\hline Gyógyítás iránt érzett motiváció átlagos & 7,151 & 2,959 & 15,788 & 6,446 & 14,967 & 2,284 & 0,507 & 0,258 \\
\hline Gyógyítás iránt érzett motiváció átlag feletti & 8,143 & 2,916 & 15,007 & 5,191 & 15,251 & 2,265 & 0,597 & 0,285 \\
\hline Szakmai színvonal átlag alatti & 8,378 & 1,872 & 20,134 & 6,641 & 15,438 & 3,283 & 0,436 & 0,103 \\
\hline Szakmai színvonal átlagos & 7,831 & 2,936 & 14,6562 & 5,233 & 15,292 & 2,404 & 0,853 & 0,273 \\
\hline Szakmai színvonal átlag feletti & 8,205 & 3,002 & 15,539 & 5,635 & 15,132 & 2,172 & 0,588 & 0,287 \\
\hline
\end{tabular}

helést jelent a munkavállalók számára, amit tovább nehezíthet a munkavesztéstől vagy a jövőtől való félelem, amely már az egészségügyi felsőoktatási rendszerben lévő hallgatók diákéveiben is tapasztalható. Ez a negatív érzés a munkavégzés során tovább hatványozódhat a betegellátás, a gondozás, illetve a lelki támogatás nyújtása során $[11,12]$. Tág spektrumon mozog azon szakirodalmak száma, amelyek az Erófeszítés-Jutalom Egyensúlytalanság Kérdőív nemzetközi változatát használták: eredmények kerültek közlésre a munkahelyi stressz depressziót, szív- és érrendszeri, illetve a mozgató szervrendszert érintő betegségek, valamint a pályaelhagyási magatartást kiváltó hatásáról is [13-15].

Eredményeink szerint az életkor szignifikánsan nem befolyásolja a munkahelyi stressz-szintet, azonban egy pozitív irányú, gyenge erősségú lineáris kapcsolat volt kimutatható a két változó között, amely csekély mértékben befolyásolta az általunk vizsgált stresszhányadost. A mintánk tagjai körében tapasztalható, az életkorral növekvő magasabb stresszpontszámok hátterében a korlátozott előléptetési lehetőségekből fakadó frusztrációt feltételezzük. Nem találtunk számottevő kapcsolatot a munkahelyi stressz-szint pályaelhagyási és migrációs magatartást befolyásoló hatásában, így eredményeink a más egészségügyi szakdolgozók körében készült, ugyanezen kérdőív segítségével mért munkahelyi stressz-szint migrációs és pályaelhagyási magatartást befolyásoló hatásának vizsgálata során keletkezett eredményekhez képest eltérést mutatott. Ennek hátterében az állhat, hogy a felhasznált szakirodalmakban a részt vevők jelentős része ápoló volt, így heterogén az iskolai végzettségük, munkavégzésük (három múszak, 12 órás napi beosztás), valamint az ebből fakadó számos betöltött munkahelyi pozíció (segédápoló, szakápoló, osztályvezető, intézményvezetô ápoló) eltérő [16-18]. Mintánkban elenyésző csoport fejezte ki elégedettségét a munkáltatója anyagi megbecsülésével kapcsolatban (6,5\%). A magánszférában munkát vállalók körében volt kifejezett a bérezéssel kapcsolatos elégedettség, azonban ebben a csoportban volt a legmagasabb a munkahelyi stressz-szint is. Ezt a praxisalapítás financiális kockázatának a viselésével magyarázzuk.

A válaszadók nagy aránya számolt be munkahelyén tapasztalható kedvezőtlenül alakuló jellemzőkről, amelyek közül az anyagi megbecsülésben tapasztalható elégedetlenség volt a legjellemzőbb negatívum. Mintánkban a kedvezőtlen anyagi és erkölcsi megbecsüléssel szembesülő kollégák hajlamosabbak elhagyni a gyógytornászpá- 
lyát, mint azok a társaik, akik esetében pozitívan alakulnak ezek a jellemzók. Véleményünk szerint egy kiterjesztettebb, akár más szakmákat is felvonultató adatbázis eredményeinek elemzése során is hasonló következtetéseket vonhatnánk le, mivel számos, e témában született publikáció eredményeiben közlésre került, hogy a pályaelhagyási magatartás hátterében elsődlegesen a kedvezőtlen anyagi, illetve erkölcsi megbecsülés áll $[19,20]$. A férfiak csoportjában tapasztalható magas külföldi munkavállalási hajlandóság vélhetően a családfenntartói szerepből fakad, ugyanakkor a nők körében is gyakori, mivel mintánk tagjai közül a nők jóval magasabb arányban képviselték magukat. Jellemző volt a mintánk tagjainak körében kifejezett elégedetlenség a szakma által nyújtottakkal szemben. A rossz tapasztalatokból fakadóan többen elhagynák az egészségügyi pályát, valamint ismerőseiknek, barátaiknak sem ajánlanák ezt a foglalkozást [21-23]. A megkérdezettek kétharmada eltérő mértékben ugyan, de elégedetlen jelenlegi élethelyzete valamely aspektusával. Eredményeink szerint amennyiben egy kolléga nem számol be teljes mértékű megelégedettségről jelenlegi élethelyzetével kapcsolatosan, az szignifikáns hatást fejt ki a pályaelhagyási tervek meglétére is. $\mathrm{Az}$ állás elvesztésétől való félelem statisztikailag nem befolyásolja a megkérdezettek pályaelhagyási magatartásának bekövetkezését, ugyanakkor, ha egy gyógytornász kolléga fél állásának elvesztésétől, jellemző, hogy pályaelhagyási tervei is vannak. Eredményünk jól korrelál a felhasznált szakirodalmakban megfogalmazottakkal, ugyanis azok a kollégák, akik biztosnak érzik jelenlegi állásukat, nem éreznek jelentősebb motivációt a pályaelhagyásra. A gyógytornászszakmától eltérő végzettség megléte jelentősen befolyásolja a minta pályaelhagyási magatartásának bekövetkezését: azok a kollégák, akik rendelkeznek más képesítéssel is, közel háromszoros eséllyel hagyhatják el a gyógytornászszakmát. A munkahelyi környezet minősége nem mindig alakul a munkavállaló által elvártak szerint, ebben az esetben a család támogató ereje protektív tényezóként hathat a pályaelhagyási magatartás esetleges bekövetkezésében [24]. A nemzetközi migrációs magatartás hátterében, a pályaelhagyáshoz hasonlóan, ugyancsak komplex okok találhatók meg. Leginkább a jelenlegi munkahelyen tapasztalható kedvezőtlen anyagi és erkölcsi megbecsülés, illetve a szakmai előrelépés hiánya válthatja ki az anyaország elhagyását $[25,26]$. A külföldi munkavállalást tervezők leggyakrabban a célországban tapasztalható kedvezőbb anyagi javadalmazás, ezáltal a család jobb életszínvonalának megteremtése miatt vállalkoznak az országhatáron túli munkavégzésre [27]. Mind saját vizsgálatunk, mind e témában született korábbi felmérések eredményei alapján kijelenthető, elengedhetetlen az egészségügyi szférában munkát vállalók szolgálatait anyagilag és erkölcsileg is megbecsülni, továbbá a megfelelő finanszírozási hátteret biztosítani [28-33].
Anyagi támogatás: A közlemény a „TÁMOP-4.1.1.C13/1/KONV-2014-0001 Az élettudományi-klinikai felsőoktatás gyakorlatorientált és hallgatóbarát korszerüsítése a vidéki képzőhelyek nemzetközi versenyképességének erősítésére" pályázat támogatásával készült.

Szerzôi munkamegosztás: P. R., E. D., K. J.: A vizsgálat tervezése és lefolytatása. P. R., R. L. B.: Statisztikai elemzések. K. D., H. M.: Irodalomkutatás. P. R., E. D., D. T.: A kézirat megszövegezése. A cikk végleges változatát valamennyi szerző elolvasta és jóváhagyta.

Érdekeltségek: A szerzőknek nincsenek érdekeltségeik.

\section{Irodalom}

[1] Cooper, R. A., Aiken, L. H.: Health services delivery: reframing policies for global migration of nurses and physicians - a US perspective. Policy Polit. Nurs. Pract., 2006, 7(3 Suppl.), 66S-70S.

[2] Likupe, G.: Experiences of Afriacan nurses in the UK National Health Services: a literature review. J. Clin. Nurs., 2006, 15(10), 1213-1220.

[3] Boncz, I., Nagy, J.: 10 years of experince with the Hungarian DRG/HBCs system from purchaser's point of view. [A Homogén Betegségcsoportok (HBCS) rendszerének 10 éves tapasztalatai finanszírozói oldalról.] Egészségügyi Menedzsment, 2003, 5(2), 21-27. [Hungarian]

[4] Boncz, I., Dózsa, C., Kaló, Z., et al.: Development of health economics in Hungary between 1990-2006. Eur. J. Health Econ., 2006, 7(Suppl. 1), 4-6.

[5] Girasek, E., Molnár, R., Eke, E., et al.: The medical career choice motivations - Results from a Hungarian study. Cent. Eur. J. Med., 2011, 6(4), 502-509.

[6] Gulácsi, L., Brodszky, V., Péntek, M., et al.: History of health technology assessment in Hungary. Int. J. Technol. Assess. Health Care, 2009, 25(Suppl. 1), 120-126.

[7] Girasek, E., Eke, E., Szócska, M.: Analyis of a survey on young doctors' willingness to work in rural Hungary. Hum. Resour. Health, 2010, 8, 13.

[8] Kriszbacher, I., Oláh, A., Bódis, J., et al.: Health sciences research in Hungary. CMAJ, 2007, 176(6), 809-812.

[9] Salavecz, Gy., Neculai, K., Rózsa, S., et al.: Reliability and validity of the Hungarian version of the Effort - Reward Imbalance Questionnaire. [Az Erőfeszítés-Jutalom Egyensúlytalanság Kérdőív magyar változatának megbízhatósága és érvényessége.] Mentálhigiéné és Pszichoszomatika, 2006, 7(3), 231-246. [Hungarian]

[10] Garava-Gubins, I., Scott, S.: Effects of various methodologic strategies. Survey response rates among Canadian physicians and physicians-in-training. Can. Fam. Physician, 2008, 54(10), 1424-1430.

[11] Gelsema, T. I., Van der Doef, M., Maes, S., et al.: A longitudinal study of job stress in the nursing profession: causes and consequences. J. Nurs. Manag., 2006, 14(4), 289-299.

[12] Hegney, D., Plank, A., Parker, V.: Extrinsic and intrinsic work values: their impact on job satisfaction in nursing. J. Nurs. Manag., 2006, 14(4), 271-281.

[13] Li, J., Zhang, M., Loerbroks, A., et al.: Work stress and the risk of recurrent coronary heart disease events: a systematic review and meta-analysis. Int. J. Occup. Med. Environ. Health, 2015, $28(1), 8-19$.

[14] Silva-Junior, J. S., Fischer, F. M.: Long-term sickness absence due to mental disorders is associated with individual features and psychosocial work conditions. PloS ONE, 2014, 9(12), el15885. 
[15] Dercyke, H., Vlerick, P., Burnay, N., et al.: Impact of the effort reward imbalance model on intent to leave among Belgian health care workers: a prospective study. J. Occup. Org. Psychol., 2010, 83(4), 879-893.

[16] Hasselhorn, H. M., Tackenberg, P., Peter, R.: Effort-reward imbalance among nurses in stable countries and in countries in transition. Int. J. Occup. Environ. Health, 2004, 10(4), 401-408 .

[17] Lavoie-Tremblay, M., O'Brien-Pallas, L., Gélinas, C., et al.: Addressing the turnover issue among new nurses from a generational viewpoint. J. Nurs. Manag., 2008, 16(6), 724-733.

[18] Sebestyén, A., Boncz, I., Sándor, J., et al.: Response to an article in the June 2006 issue of Medical Care. Med. Care, 2006, 44(12), 1148.

[19] Ujvarine, A. S., Zrinyi, M., Toth, H., et al.: Intent to stay in nursing: internal and external migration in Hungary. J. Clin. Nurs., 2011, 20(5-6), 882-891.

[20] Buchan, J.: International recruitment of nurses: policy and practice in the United Kingdom. Health Serv. Res., 2007, 42(3 Pt 2), 1321-1335.

[21] Fochsen, G., Sjögren, K., Josephson, M., et al.: Factors contributing to the decision to leave nursing care: a study among Swedish nursing personnel. J. Nurs. Manag., 2005, 13(4), 338-344.

[22] Betlehem, J., Olah, A.: Letter to the editor: Refers to: Xtreme nursing and the nursing shortage. Nurs. Outlook, 2007, 55(4), 165 .

[23] Betlehem, J., Boncz, I., Kriszbacher, I., et al.: The export of nurses from Europe to the United States. Am. J. Public Health, 2007, 97(12), 2119

[24] Josephson, M., Lindberg, P., Voss, M., et al.: The same factors influence job turnover and long spells of sick leave - a 3-year followup of Swedish nurses. Eur. J. Public Health, 2008, 18(4), 380385.

[25] Sidebotham, M., Ahern, K.: Factors influencing midwifery migration from the United Kingdom to Australia. Int. Nurs. Rev., $2011,58(4), 498-504$.
[26] Zander, B., Dobler, L., Busse, R.: The introduction of DRG funding and hospital nurses changing perceptions of their practice environment, quality of care and satisfaction: comparison of cross-sectional surveys over a 10-year period. Int. J. Nurs. Stud., 2012, 50(2), 219-229.

[27] Duverne, A., Carnet, D., d'Athis, P., et al.: French doctors working in Great Britain: a study of their characteristics and motivations for migration. Rev. Epidemiol. Sante Publique, 2008, $56(5), 360-373$.

[28] Endrei, D., Zemplényi, A., Molics, B., et al.: The effect of performance-volume limit on the DRG based acute care hospital financing in Hungary. Health Policy, 2014, 115(2-3), 152-156.

[29] Boncz, I., Kaló, Z., Mohamed Ibrahim, M.I.B., et al.: Further steps in the development of pharmacoeconomics, outcomes research, and health technology assessment in Central and Eastern Europe, Western Asia, and Africa. Value Health Regional, 2013, 2(2), 169-170.

[30] Endrei, D., Molics, B., Ágoston, I.: Multicriteria decision analysis in the reimbursement of new medical technologies: real-world experiences from Hungary. Value Health, 2014, 17(4), 487489.

[31] Boncz, I., Sebestyen, A.: Financial deficits in the health services of the UK and Hungary. Lancet, 2006, 368(9539), 917-918.

[32] Boncz, I., Nagy, J., Sebestyén, A., et al.: Financing of health care services in Hungary. Eur. J. Health Econ., 2004, 5(3), 252-258.

[33] Boncz, I., Evetovits, T., Dózsa, Cs., et al.: The Hungarian Care Managing Organization pilot program. Value Health Regional, $2015,7,27-33$.
(Endrei Dóra dr.,

Pécs, Mária u. 5-7., 7621 e-mail: endrei.dora@pte.hu)

\section{Tisztelt Szerzőink, Olvasóink!}

Az Orvosi Hetilapban megjelenő/megjelent közlemények elérhetőségére több lehetőség kínálkozik.

Rendelhető különlenyomat, melynek áráról bővebben a www.akkrt.hu honlapon (Folyóirat Szerzőknek, Különlenyomat menüpont alatt) vagy Szerkesztöségünkben tájékozódhatnak.

A közlemények megvásárolhatók pdf-formátumban is, illetve igényelhető Optional Open Article (www.oopenart.com).

Adott dij ellenében az online közlemények bárki számára hozzáférhetök honlapunkon (a közlemények külön linket kapnak, így más oldalról is linkelhetövé válnak).

Bővebb információ a hirdetes@akkrt.hu címen vagy különlenyomat rendelése esetén a Szerkesztőségtől kérhető. 